\title{
淀川流域圏の水環境と大阪湾への影響解析 WATER ENVIRONMENT OF YODO RIVER BASIN AND ITS IMPACT ON WATER QUALITY IN THE OSAKA BAY
}

\author{
西田修三1 $\cdot$ 北畠大督 $2 \cdot$ 入江政安3 \\ Shuzo NISHIDA, Daisuke KITABATAKE and Masayasu IRIE
}

\begin{abstract}
1正会員 工博 大阪大学大学院助教授 工学研究科地球総合工学専攻 (广565-0871 吹田市山田丘2 - 1)
2学生会員 大阪大学大学院 工学研究科地球総合工学専攻 (T 565-0871 吹田市山田丘2-1)

3正会員 博 (工) 大阪大学大学院助手 工学研究科地球総合工学専攻 (₹ 565-0871 吹田市山田丘2 - 1)
\end{abstract}

\begin{abstract}
To clarify the influence of the population increase and the urban development in the Yodo River basin on the water environment of the basin area and the Osaka bay area, at first we collected present and past data of the distribution of population and the land use in the basin, and made GIS data. Water qualities were calculated by using the grid-base model with the GIS data. We proposed some measures scenarios toward environment conservation and urban renaissance, and evaluated the effect on the water environment of the basin area.

It was found that the water quality of the Yodo river basin will hardly be improved in the future though that has been considerably improved in the past 30 years. As the result of evaluating the effects of the measures scenarios, the inflow load to the Osaka bay hardly change in any case.
\end{abstract}

Key Words : Yodo River basin, Osaka bay, Grid-base model, Water quality, Basin management

\section{1.はじめに}

8, 240kn³流域面積を有する淀川水系は, 上流に琵琶 湖を, 帯の下流には大阪と京都の二大都市を抱える一級 河川であり，関西地域の社会と経済の基盤を支えている． 平均流量300m²/sに上る高負荷の淀川河川水は大阪湾奥 部に注かれ 著しく水質の悪い大和川とともに, 大阪湾 に大きな環境負荷を与えている.1950年代の高度経済成 長期に流入負荷量か急増し，1970年にピークを迎え，光 の後，1979年の総量規制の実施により急減し，淀川下流 域 (伝法大橋地点) のBODはピーク時の約10ng/Lから現 在は4ng/Lと大きく改善された . しかし , この流入負荷 量の減少ほどには大阪湾沿岸の水質改善は進まず，未だ に赤潮の発生力続き，近年は青潮も度々観測されている。 これは, 大阪湾の有機物に占める内部生産の割合が大き いことや，埋立による浅水域の消失や停滞水域の増加等 により沿岸域の水質か悪化したことが原因と考えられる． 本研究では, 淀川流域の人口増加や都市開発が流域環 境，ひいては, 大阪湾の水環境にどのような影響を及ぼ すかを明らかにするために，まず，現在および過去の流 域環境データの収集とGS化を行った · あわせて，人口 推計資料等を基に予測された将来の流域人口分布や土地

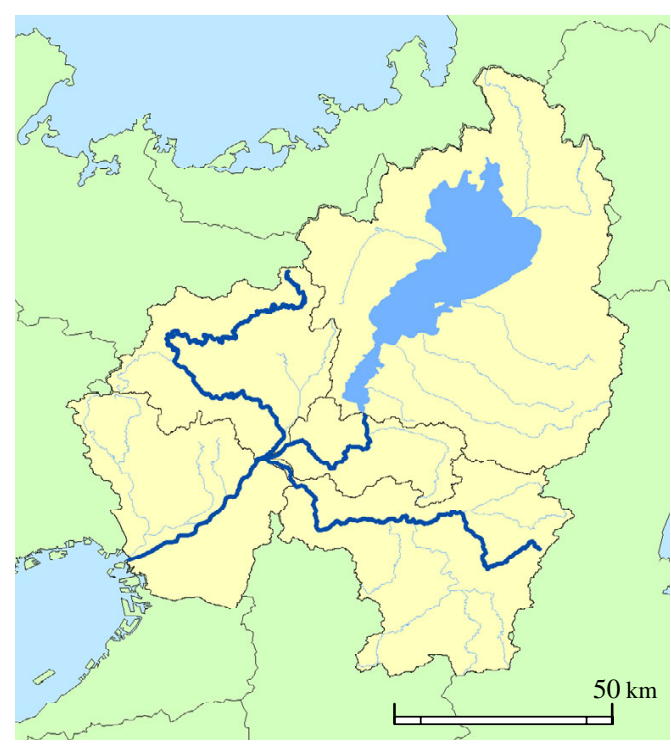

図 1 淀川流域圏

利用データのG S化も行い, 水文・水質モデルを用いた 流出解析により，淀川流域圏と大阪湾の水環境の変遷を 明らかにするとともに将来予測を行った . また，流域環 境の保全や再生に向けて提案された施策シナリオが , 流 域の水環境に及ぼす効果について評価も行った。 


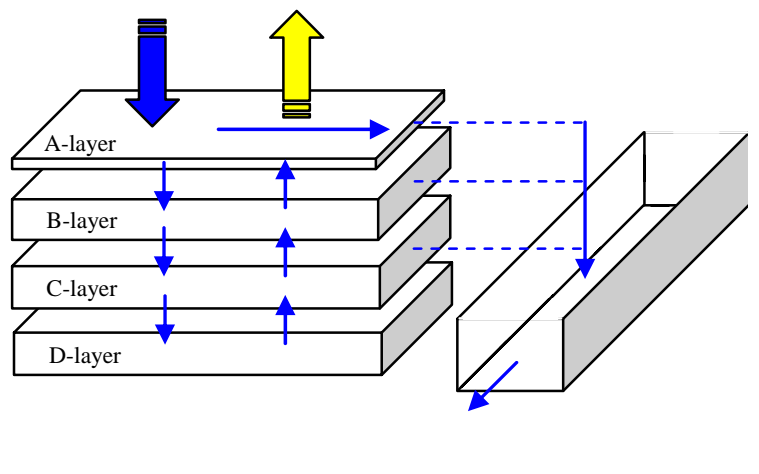

図- 2 モデル概要

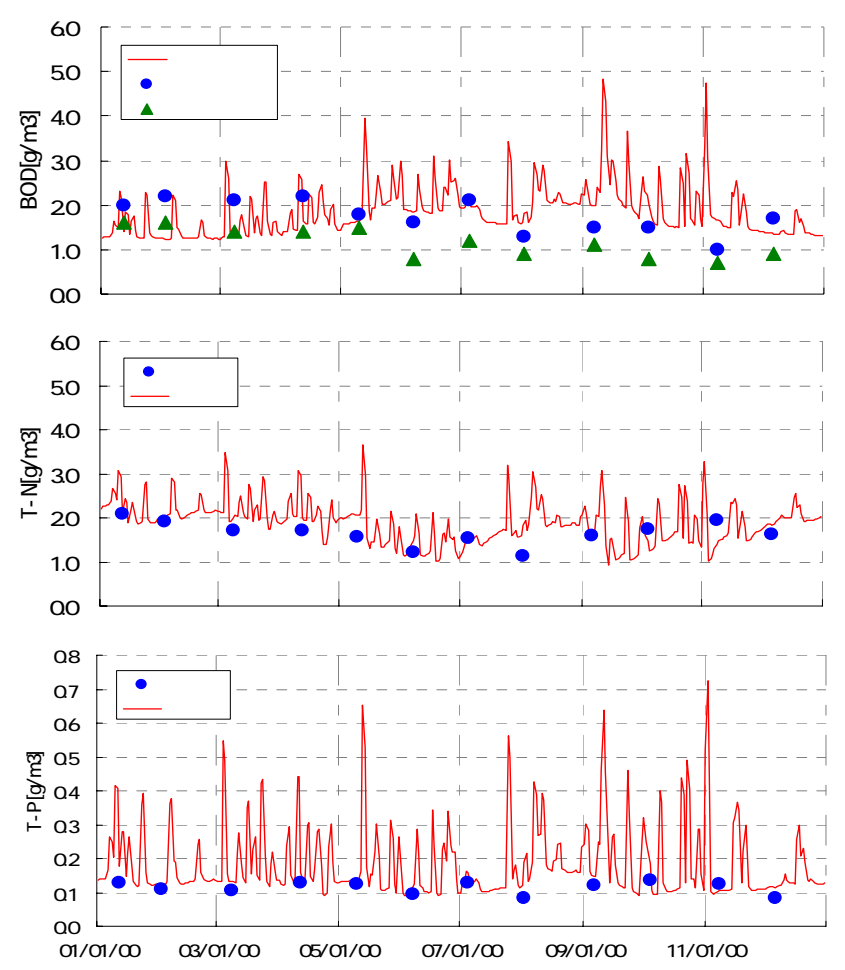

図-3 BOD, T- N, T- Pの計算結果

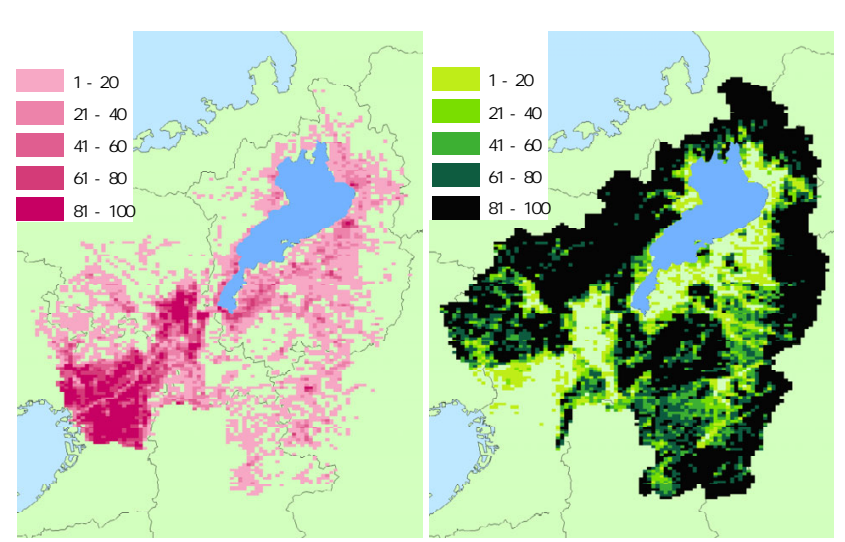

( a) 市街地

(b) 山林

\section{2 . モデル概要}

(1) グリッドモデル

水平方向には分布型のグリッドモデルを採用し , 図- 2 に示すように鉛直方向には4層の線形貯留モデルを適用

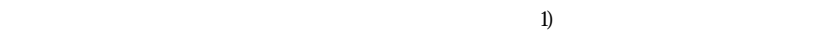
たモデルと同樣である .グリッドサイズは1 $\mathrm{kmx} 1 \mathrm{~km}$, 総 数8242個（琵琶湖を除くと7557個）である.土地利用の 状況は「山林」「水田」「畑」「市街地」「水域」「炎 の他」に分類し，各グリッド上の面積率（％) として数 值化した . 落水線は, 低平地等においても計算か河能な ように, 国土数值データの流路位置および流域界データ を基に定義した。

\section{（2）水文モデル}

降水量からグリッド毎に算出された蒸発量を減じ、有 効降雨量とした .グリッドの表面流およびA層には ki nemat i c wave モデルを適用し，B〜D層には線形貯蓄 モデルを適用した . 土地利用状況の差異は表面流および A層に考慮される . 水田は灌溉期と非灌溉期を計算に反 映させるため, 表面流とA層にタンクモデルを適用した . また , グリッド中央に仮想河道を設定し全流出量を流入 させ , 兴の河道流量をグリッドの流出量として算定した . 各層の飽和水量を上回った差分は上層に復帰させ , A層 の飽和水量の差分は表面流に流下させた .

琵琶湖および流域ダムからの放流に関しては , 流量制 御を考慮したモデル2 も提案されているが, 今回は実際 の放流量を境界条件として与えた . また , 流域には取水 地点およひ排水地点も設置し流出入を考慮している.

気象データは，10ヶ所のSDP観測データをティーセン 法により各グリッドに割り振つた .

\section{（3）負荷量の算定}

負荷量算定には幾つかの方法力提案されているが(3), 4)， ここではL-Q式によって負荷量の推定を行った . 流域内 の各水質観測点の観測データを基に，土地利用別にL- Q 式を求め，BOD，T- N , T-Pの負荷量を推定した．また， 人口増加に対応させて将来の下水道普及率を予測し負荷 量計算に反映させた . 2000年の水質 (BOD , T- N , T-P) の計算結果を図-3に示す．水質観測か実施されている平 水時の計算結果を見る限り，再現性は良好と考えられる。

\section{3 . 流域の水環境の変遷と将来予測}

\section{(1) 土地利用状況の変化}

淀川流域の土地利用の変化が水環境に及ぼす影響を明 らかにするために，1970年(過去)，2000年(現在)，2035 年(末来) を対象にシミュレーションを実施した . 2035年 


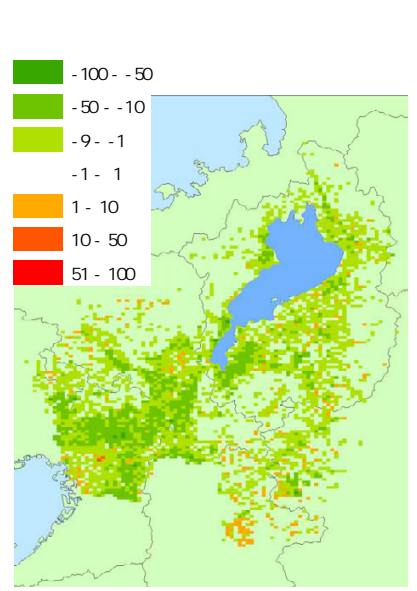

(a) 市街地

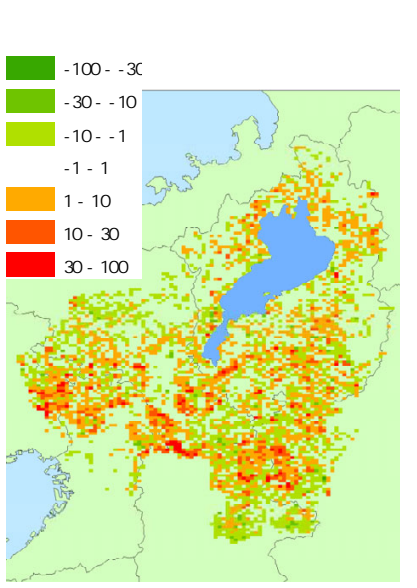

(b) 山林

図-5 土地利用の变化 (1970～2000年)

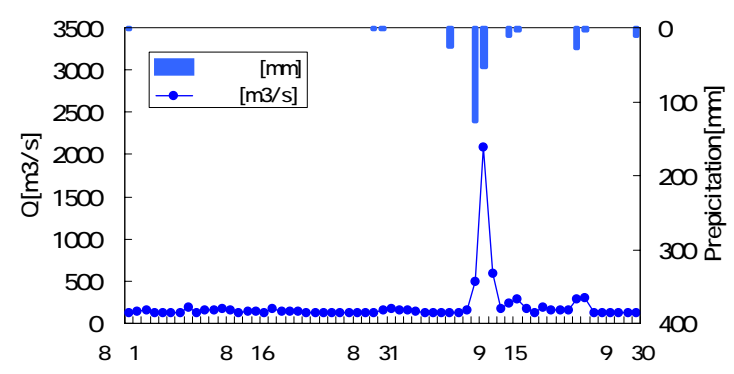

図- 7 流量と降水量(枚方, 2000年)

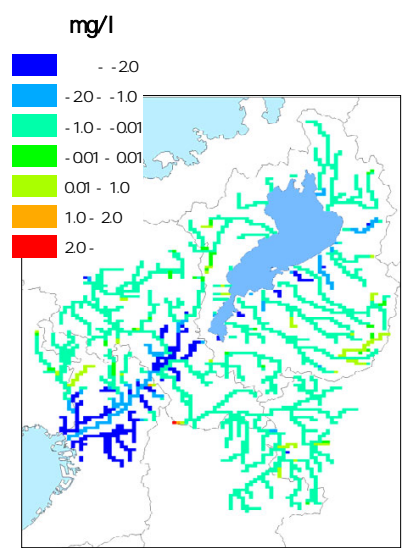

(a) 1970 2000年

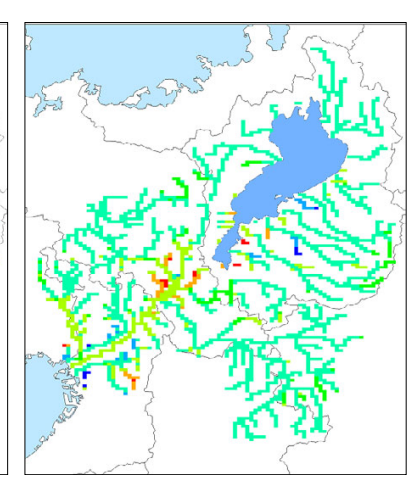

(b) 2000 2035年

図-9 BODの变化量

については , 国立社会保証人口問題研究所の2030年の 人口推計値と, 過去の土地利用状況の变動傾向を基に予 測しGS化を行った . 作成した現在の土地利用G Sデータ を図-4に示す．また，図-5，図一には光れ光れ土地利用

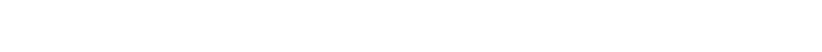
合は，1970年には市街地10\%，森林59\%，農地17\%で あつたが，2000年には13\%，58\%，15\%，さらに2035年 には12\%，59\%，13\%と変化している.大阪，京都を抱 える下流域では, 過去30年間に都市化か淮行したが，森 林が大半を占める琵琶湖上流域ではほとんと変化は見ら れない.

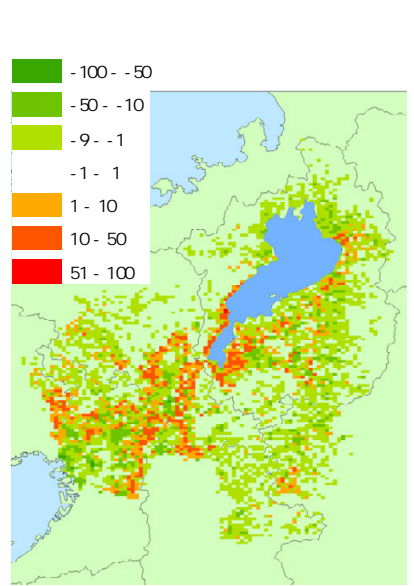

( a) 市街地
凡例 $\%$ )

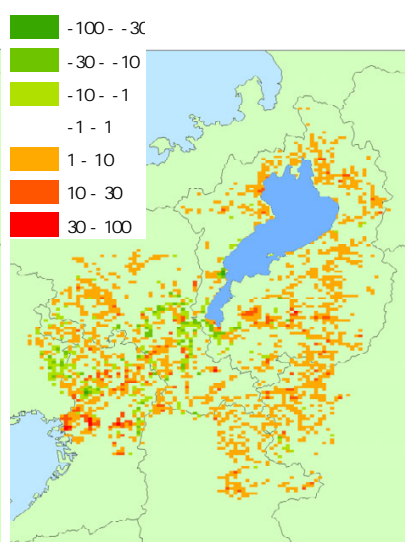

図-6 土地利用の変化 (2000～2035年)

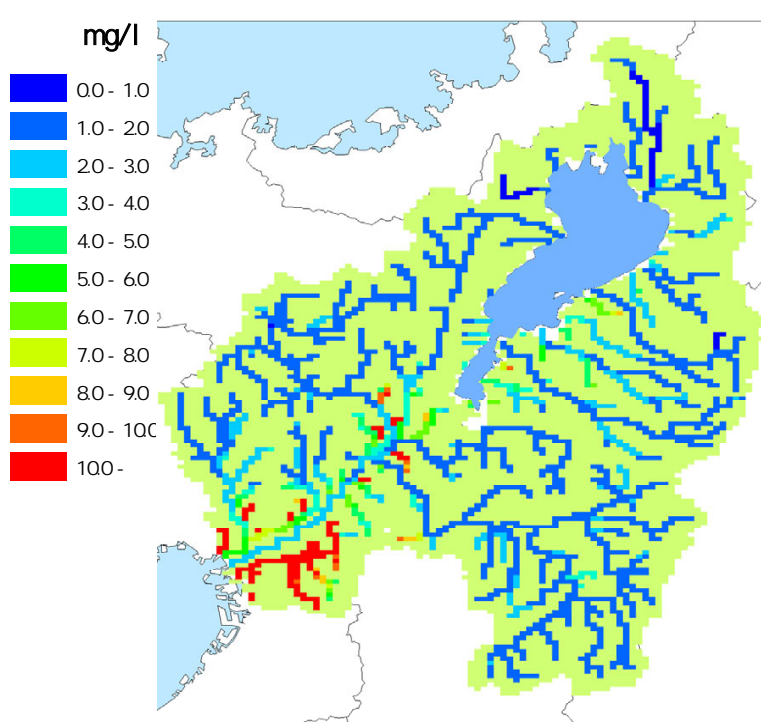

图-8 2000年のBOD分布

\section{(2) 計算結果}

図-7に示すように,一度の出水 $\left(2100 \mathrm{~m}^{3} / \mathrm{s}\right)$ があった 2000年8月11日〜9月30日の51日間を対象に水質シミュ レーションを行った .一例としてBODの計算結果を図-8， 図-9に示す . 図-8は2000年のBOD分布を, 図-9は2000年 を基準としたBODの変化量 (負值か改善) を表している. BOD濃度は, 計算期間のBOD輸送量を総流量て除した平 均濃度で示している.2000年の流域全体のBODの平均濃 度は2.2ng/L, 1970年のBODの濃度平均は3.2ng/Lであ り, 1970年から2000年にかけて全体的にBOD濃度の低下が 見られた. 淀川河口部では1 Ong/L程度の水質改善か確認 された . 2035年にかけての流域全体のBOD平均濃度は

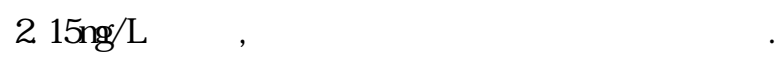

図-10は，代表地点のBOD濃度を示したものである。 BOD濃度は桂川で高く, 木津川で低く, 淀川本川では大 きな水質変化は見られない .このような傾向はどの年も 


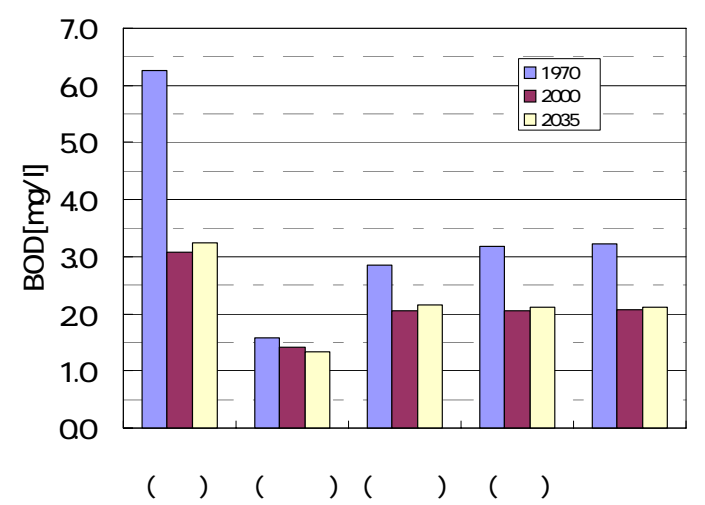

图-10 流下方向の水質変化

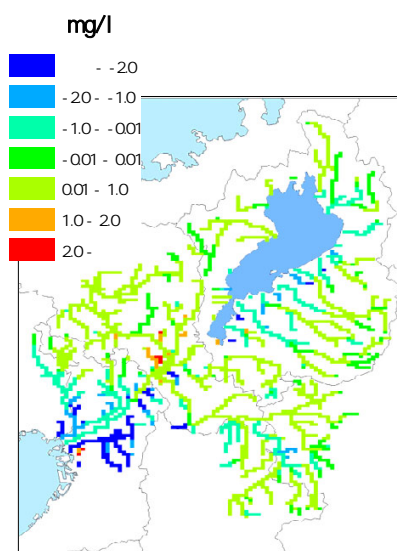

(a)二極集中型

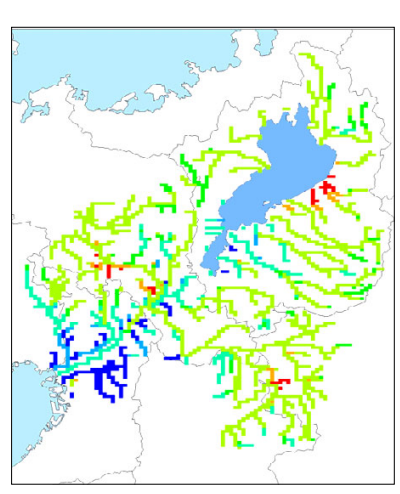

(b) 圈域分散型
图-12BODO変化量

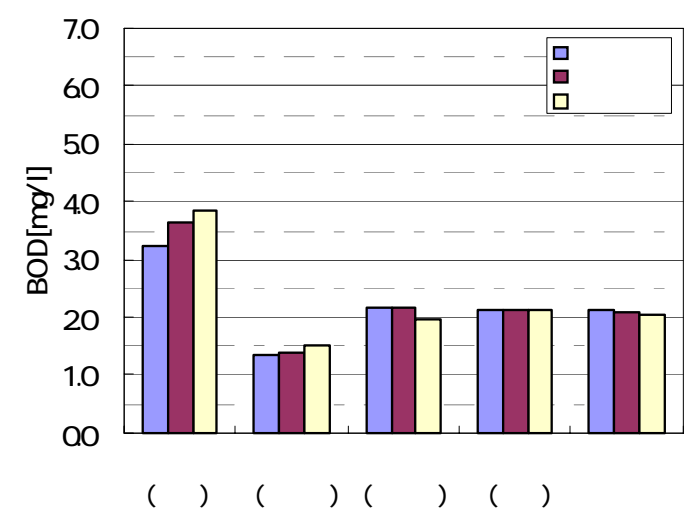

图 13 流下方向の水質変化

表- 1 施策シナリオ

\begin{tabular}{|c|c|}
\hline 二極集中型 & 圏域分散型 \\
\hline 大阪市と京都市を流域圏の社会 & 二極集中型シナリオの大阪市と \\
\hline 活動の核都市として設定し，周 & 京都市に加えて , 高槻市 , 大津 \\
\hline 辺で人口を増加させるシナリ & 市，彦根市を新たな拠点とし， \\
\hline オ。主として，大阪の都心6区 & 計5都市を流域圈の社会活動の核 \\
\hline (北区, 中央区, 福島区, 天王 & 都市として設定し，周辺で人口 \\
\hline 寺区, 西区, 浪速区) 及び京都 & を増加させるシナリオ。 \\
\hline 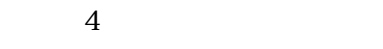 & \\
\hline $\begin{array}{l}\text { 京区, 東山区) の発展を想定し } \\
\text { ている。 }\end{array}$ & \\
\hline
\end{tabular}

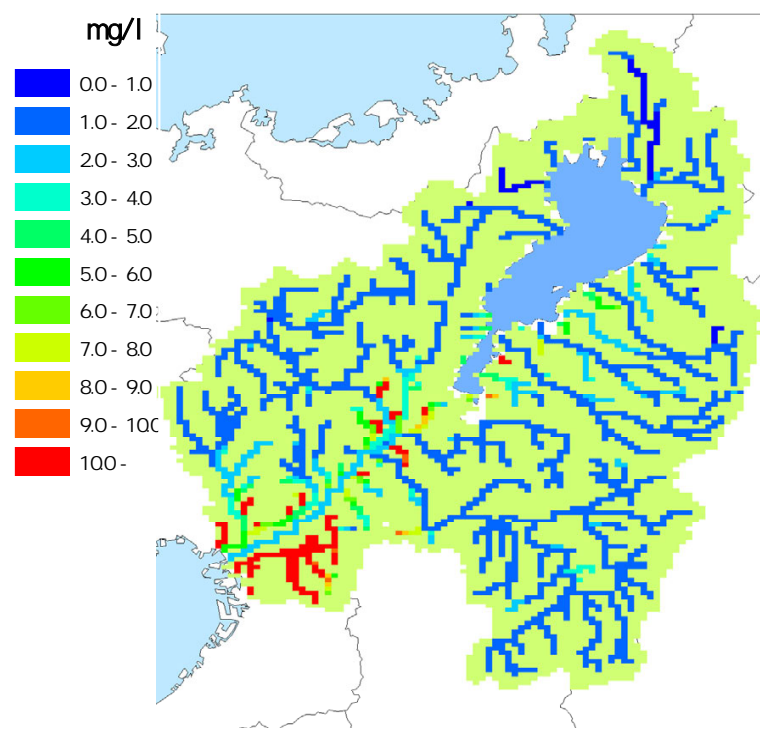

图-11 BOD分布(2035年)

同じであるが，図-9の平面分布にも見られるように， 1970年から2000年にかけて桂川の納所地区でBODが約 50\%改善され、光の影響が本川下流域に及び約 $30 \% の$ B0Dの低下が見られる . この桂川の水質改善は, 下水道 の整備によるところが大きいと考えられる．2000年〜 2035年のBOD濃度の変化は小さく,下流域では僅か 0.1ng/L程度であることがかか .

\section{4 . 施策シナリオに対する水環境評価}

\section{(1) 施策シナリオ}

筆者らが参画した研究プロジェクトワにおいて, 流域 環境の保全と改善に向けて, 幾つかの誘導型施策シナリ 才を提案し，关の効果の检証を行っている.流域圈の都 市再配置や土地利用誘導等を考え立案された，二極集中 型, 東海道集中型, 圈域分散型, 農村回帰型の 4 つの施 策シナリオについ, 道路交通, 都市気象, 生態系, 大 気環境，水環境について谷の効果を評価し，また，流域 の森林管理についても, 水土保全型, 生物多核性保全型, 二酸化炭素吸収促進型の3つの管理施策について検討を 行っている.シナリオの検討結果の詳細は研究プロジェ

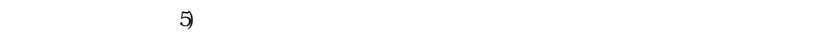
都市化に関係する表-1に示す2種類のシナリオ（二極集 中型，圈域分散型）について, 解析結果を述へる。

\section{(2) シナリオの評価}

前章でも解析した2035年のBO濃度の将来状況（施策 を講じない自然発展型) を图-11に，二極集中型および 圈域分散型シナリオの施策を行った場合のBOD濃度の变 化量を图-12に示す . 流域全体のBOD平均濃度は, 二極集 


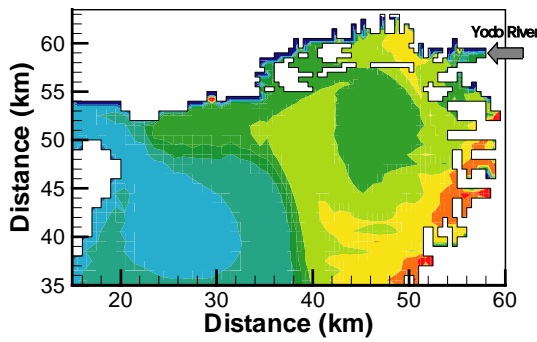

(a) 1970年

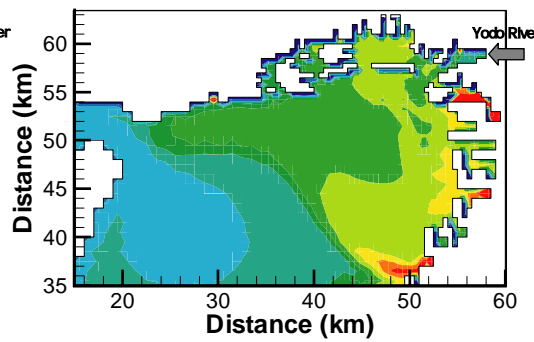

(b) 2000年

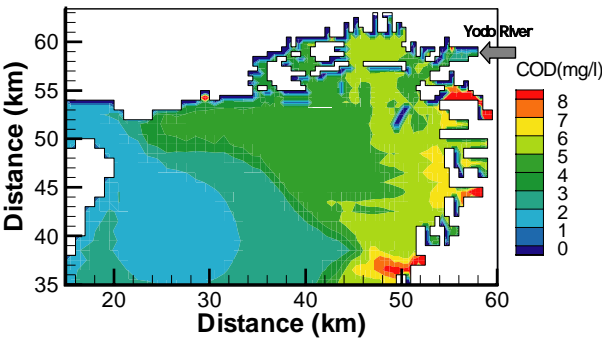

(c) 2035年

図-14 大阪湾奥部の表層COD分布

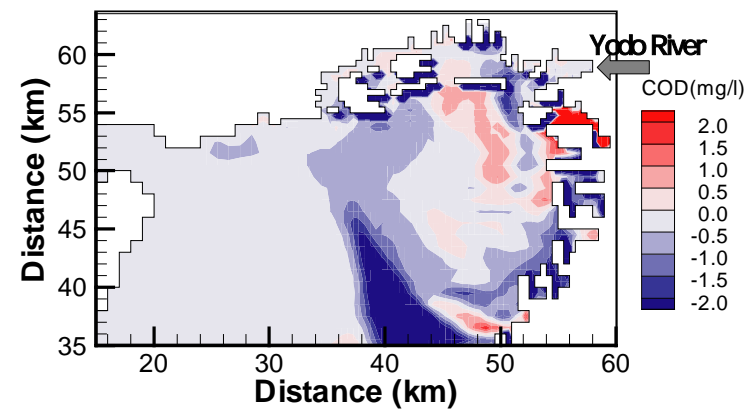

( a) 1970 2000年

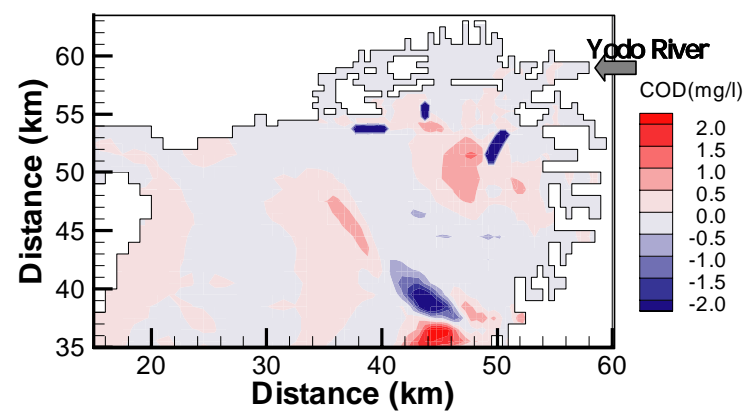

(b) 2000 2035年

図-15 大阪湾奥部の000变化量

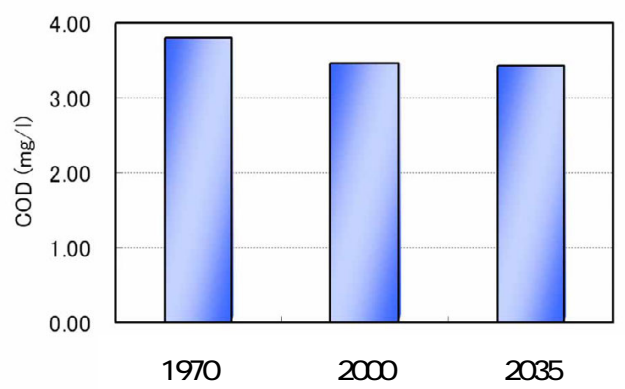

图- 16 大阪湾全域の00平均濃度

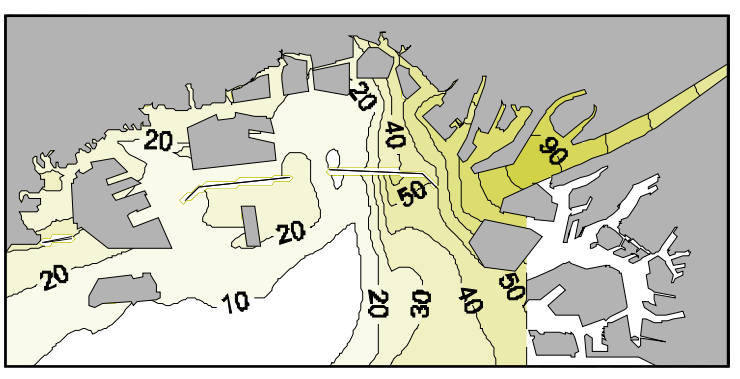

図-17 陸起源有機物の堆積割合 $(\%$

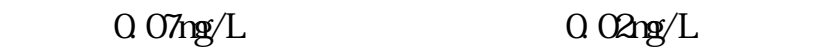
示した . 計算で得られた代表地点の濃度を図一13に示す。 二極集中型では桂川のみに影響力現れ約10\%の濃度上昇 か泩じたが , 圏域分散型では桂川と木津川において悪化 し宇治川では改善傾向がみられた . 桂川においてシナリ オの影響が大きく現れたのは, 市街化率の変化に起因し ている。市街化面積の増加による都市化は, 負荷量の増 加を生じる . 本モデルでは人口増加に対応させて下水道 普及率を向上させているが, 兴の効果を上回る負荷の増 加力甡じたことを意味している．しかし，いずれの場合 も淀川下流域への影響は少なく, 大阪湾への流入負荷は ほとんど変わらなかった .

流域全体の平均として水質を捉えた場合には，二極集 中型の流域構造が他の3つのシナリオに比べて最も水質 改善の効果が大きかった . 二極集中型シナリオでは上述 のように局所的な水質悪化は見られるが , 流域の面源負 荷の減少による効果が大きく現れ，平均濃度としては約 3.7\%の改善効果か現れた .

\section{5 . 大阪湾に及ぼす影響解析}

\section{(1) 水質シミュレーション}

淀川流域における土地利用の変化が大阪湾の水質に及 ぼす影響を確かめるために, 1970年，2000年，2035年を 対象に水質のシミュレーションを実施した . 1970年の計 算では, 海岸地形を当時の地形に戻し，水文モデルに よって得られた淀川下流端における流量および水質を境 界条件として与えた . 底質については当時の詳細なデー タがないため, 現状值を与えた . また，2035年の将来予 測計算においては，1970年の計算と同樣，底質について は現状のままとし，流入負荷については人口や下水処理 等の将来予測值を基に計算された水文モデルの計算結果 を境界条件として与えた .なお，地形については神戶空 港や関西空港の埋立拡張等の新規埋立地を考慮した . た だし, 計算結果の図化においては簡単のため現況地形で 示している。大阪湾の流動と水質の3次元計算には，入 
江らののモデルを使用している .

流域と閉鎖性水域の環境改善政策の検討ツールとして， 同樣のモデル研究か東京湾においてもなされている゙ .

\section{(2) 計算結果}

図-14に大阪湾の表層の0分布を示す .どのケースにお いてもの0分布は潮汐フロントの存在する水深20nの等深 線より東側の海域で高くなっている . 特に尼崎西宮芦屋 港，堺泉北港沿岸において高い值を示すことかわかる．

CODの濃度变化量 (負值力改善) を図-15に示す. 1970 年に比べると2000年には埋立により河口位置や海岸線が 沖合に前進し, 湾奥部て形成されていた循環流が弯央に 向けて移動したことが流動の計算結果から確認された . この影響により河口より沖合数kmの範囲でのDか増加し たものと考えられる . しかし，他の海域ではのD值は減 少傾向を示し，陸域からの負荷の減少か涾質改善に僅か ではあるが貢献していることがわかる .

2000年から2035年にかけては , 神戶空港の建設や関西 空港の拡張などの新規埋立により，光れらの周辺海域で ○0濃度の増減がみられる．しかし，流入負荷の減少が 小さくほとんと変化がなかったため, 水質改善は認めら れない. 図-16に大阪湾全域のCODの平均濃度を示す . の結果からも，将来に向けてほとんど水質改善が進まな いことがわかる

前章て評価を行つた2つの施策シナリオを含む，4つ すべてのシナリオについて計算を行った結果, 淀川流域 の土地利用や人口分布の変化等は, 大阪湾の水質にはほ とんど影響を及ぼさず，むしろ沿岸地形の改変に伴う流 動变化や底質改善の方が大阪湾の水質に大きく作用する ことがわかった .

\section{（3）流出有機物の影響}

淀川から流出した陸或起源の有機物の挙動を知るため に，底質調查を2004年に実施した ${ }^{8}$. 河口沿岸域て採取 された底泥の炭素安定同位体比より陸起源有機物( 27\%0) と海起源有機物 $(20 \%$ ) の混合比を算定し, 弚れを陸起源 有機物の堆積割合と考えて図示したのか図-17である .

この結果を見ると，陸起源有機物の影響域は淀川河道 部と沿岸数kmの範囲に限られ，ほとんどの陸起源有機物

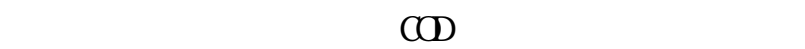
の影響は極めて小さいことがわかる .

\section{6.おわりに}

本研究ではグリッドモデルを用いた流出解析により， 淀川流域圏と大阪湾の水環境の将来予測を行うとともに， 流域環境の保全や再生に向けた誘導型施策シナリオの効 果について評価を行った . 得られた主要な結論は以下の とおりである .
（1）大阪，京都を抱える下流域では，過去30年間に著し く都市化が進んだが，森林が65\%を占める琵琶湖上流で はほとんと変化は見られない .

（2）1970年から2000年にかけてほとんどの地域でBODの 低下が見られ，特に水質悪化が進んでいた桂川流域にお いて著しい水質改善力認められた . 兴の結果，本川下流 域においてもBOD喲30\%低下した .

（3）二極集中型の流域構造が他のシナリオに比べて最も 水質改善の効果が大きかった . しかし，いずれの場合も 淀川下流域への影響は少なく, 大阪湾への流入負荷の変 化はほとんど見られなかった .

（4）これまて陸域からの負荷の削減が大阪湾の水質改善 に勤かながら貢献してきたが, 将来に向けては流入負荷 の減少がほとんど見込めず, 水質改善は進まないと予測 される .

(5) 淀川流域の土地利用や人口分布の変化等は, 大阪湾 の水質にどれほど大きな影響を及ぼすことはなく，むし ろ地形改変や底質改善等の方が大阪湾の水質を大きく変 化させる .

謝辞 : 本研究の一部は環境技術開発等推進事業 (自然再 生型流域圏・都市再生技術研究 : 研究代表者 加賀昭 和)により実施したものであることを報告するとともに， こ協力頂いた方々に感謝の意を表します。

\section{参考文献}

1) 小尻利治・東海明宏・木内陽一 : シミュレーションモデルで の流域環境䅉価手順の開発, 京都大学防災研究所年報, 第41 号B 2 , pp. 119 . 134 , 1998.

2) 佐山敬洋・立川康人・寶馨 : ダム群流況制御を考慮した広域 分布型流出予測システムの開発, 京都大学防災研究所年報, 第47号B, pp. 1- 16, 2004.

3) 野村佐和美・野口正人・西田渉・水野良宣 : G Sデータを用 いた非点源污蜀負荷流出量の予測と評価, 水工学論文集, 第 47巻, pp. 1021-1026, 2003.

4) 野原昭雄 他: グリッドベースの分布型污蜀負荷流出モデル の開発と適用，水工学論文集，第47巻, pp. 1027-1032，2003.

5) 加賀昭和 他 : 流域圏自然環境の多元的機能の劣化診断手法 と健全性回復施策の効果評価のための統合モデルの開発, 環 境技術開発等推進事業研究開発成果報告書, 258p, 2006 .

6) 入江政安・中辻啓二・西田修三 : 大阪湾における貧酸素水塊 の挙動に関する数值シミュレーション, 海岸工学論文集 , 第 51巻, pp. $926.930,2004$.

7) 安間智之 - 小路岡尖 - 伊藤弘之 · 藤田光 : 流域水物質循環 モデルを用いた東京湾と流入河川における水質変遷再現につ いて, 水工学論文集, 第50巻, pp. 1381- 1386, 2006.

8) 西田修三・入江政安・中辻啓二 : 大阪湾奥部沿岸域における 懸濁態物質の挙動と底泥特性, 海岸工学論文集, 第53巻, pp. $991-995,2006$.

(2006. 9. 30受付) 